Received: 2018.12.01 Accepted: 2019.02.12 Published: 2019.04.19

\title{
Verrucous Carcinoma of the Vulva: A Case Report and Literature Review
}

Authors' Contribution: Study Design A Data Collection B Statistical Analysis C Data Interpretation D Manuscript Preparation E Literature Search F Funds Collection $G$
BCDEFG 1,2 Wei Zhang

D 1,3 Yongyi Wang

BD 1,4 Wei Chen

D 3 Jingyun $\mathrm{Du}$

A 3 Libing Xiang

B 1,2 Shuang Ye

AC 1,2 Huijuan Yang
1 Department of Gynecological Oncology, Fudan University Shanghai Cancer Center, Fudan University, Shanghai, P.R. China

2 Department of Oncology, Shanghai Medical College, Fudan University, Shanghai, P.R. China

3 Department of Obstetrics and Gynecology, Shanghai Baoshan Luodian Hospital, Shanghai, P.R. China

4 Department of Obstetrics and Gynecology, Minhang Hospital, Fudan University, Shanghai, P.R. China
Corresponding Author: Conflict of interest:
Huijuan Yang, e-mail: huijuanyang@hotmail.com None declared

\begin{tabular}{|c|c|}
\hline Patient: & Female, 50 \\
\hline Final Diagnosis: & Verrucous carcinoma of the vulva \\
\hline Symptoms: & Itch • tumor \\
\hline Medication: & - \\
\hline Clinical Procedure: & Surgery \\
\hline Specialty: & Surgery \\
\hline Objective: & Rare disease \\
\hline Background: & $\begin{array}{l}\text { Verrucous carcinoma (VC) of the vulva is a variation of squamous carcinoma (SCC). Etiology and treatment of } \\
\text { VC are still unclear. }\end{array}$ \\
\hline Case Report: & $\begin{array}{l}\text { A 50-year-old female visited our clinic with a giant vulvar tumor ( } 8 \mathrm{~cm} \text { of diameter maximum). Biopsy revealed } \\
\text { a suspicious well differentiation squamous cancer. PET/CT (positron emission tomography/computed tomog- } \\
\text { raphy) scan found suspicious lymph node in bilateral iliac vessel region and bilateral inguinal region. She un- } \\
\text { derwent radical vulvectomy and bilateral inguinal lymph node dissection, and bilateral pelvic lymph node dis- } \\
\text { section. Pathology turns out to be VC and no lymph nodes involvement. Due to the large defection, vulvar } \\
\text { reconstruction was performed } 5 \text { weeks later using skin grafts and pudendal thigh flap. This patient was dis- } \\
\text { ease free after } 12 \text { months follow-up. }\end{array}$ \\
\hline Conclusions: & $\begin{array}{l}\text { In patients with VC, a satisfactory biopsy is important and systemic inguinal lymphadenectomy might be omit- } \\
\text { ted. For patients with large defection, flap-based reconstruction is recommended. }\end{array}$ \\
\hline
\end{tabular}

MeSH Keywords: $\quad$ Carcinoma, Squamous Cell • Carcinoma, Verrucous • Lymph Node Excision • Vulvar Neoplasms

Full-text PDF: https://www.amjcaserep.com/abstract/index/idArt/914367

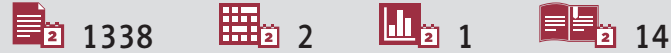




\section{Background}

Verrucous carcinoma (VC) is a very rare variant of squamous cell carcinoma (SCC) that accounts for less than $1 \%$ of VC [1]. VC were first described in 1948 by Ackerman [2], and other locations, such as cervical, vagina, and bladder, have also been described [3].

As VC is a rare disease, all cases of vulvar VC were reported in case or case series. Pathogenesis and treatment remain unclear. The precursors of VC and the relationship between human papillomavirus (HPV) infection and VC is controversial. Vulvar acanthosis with altered differentiation has been considered a precursor of VC, and although HPV testing is negative in most cases, the role for HPV is doubtful [4]. In addition, surgical treatment and follow-up therapy needs to be further discussed. VC usually presents with giant tumor size and palpated inguinal lymph nodes, however, metastasis of those palpated lymph nodes are rare.

We report a case of VC treated in Fudan University Shanghai Cancer Center (FUSCC) and reviewed the cases reported during January 1, 1998 and March 31, 2018 in PubMed. The aim of this study was to clarify the clinicopathologic characteristics of VC and optimal treatment of the disease. The study was approved by the ethics committee in FUSCC, Shanghai, China, and informed consent was obtained.

\section{Case Report}

She suffered vulvar pain and itch for almost 20 years. She visited a gynecologist and was diagnosed as having a white lesion of the vulva without pathology confirmation. Five months ago, the patient found a vulvar mass of $1.0 \mathrm{~cm}$ and biopsy confirmed papilloma of squamous epithelium. She was diagnosed as vulvar condyloma acuminate and underwent laser treatment. However, the patient developed a giant tumor in the next 5 months ( $8 \mathrm{~cm}$ of diameter maximum). Then, she consulted in Department of Gynecological Oncology, FUSCC. On clinical examination, an exophytic tumor of $8 \mathrm{~cm}$ in maximum was involving mons pubis and without urethra and vagina involvement. Enlarged lymph nodes were palpated in bilateral inguinal region. Tumor biomarker squamous cell carcinoma antigen (SCCA) was $7.8 \mathrm{ng} / \mathrm{mL}$. PET/CT Positron emission tomography/computed tomography PET/CT scan found suspicious lymph node in bilateral iliac vessel region and bilateral inguinal region. Biopsy of the vulvar lesion revealed a suspicious well differentiation squamous cancer. The patient underwent radical vulvectomy and bilateral inguinal lymph node dissection, and bilateral pelvic lymph node dissection was performed trans laparoscopy. Pathological examination of the specimen confirmed a $7.5 \times 5 \times 4.5 \mathrm{~cm}$ VC with negative margin and a $<1 \mathrm{~mm}$ stroma invasion but no vessel invasion. There was no sign of metastasis of the removed lymph nodes (0/58). According to FIGO 2009 staging criteria, the tumor was classified as IB (size $>2.0 \mathrm{~cm}$ ). Due to the large defection, vulvar reconstruction was performed 5 weeks later using skin grafts and pudendal thigh flap. All flaps survived without infection or necrosis (Figure 1). This patient was disease free after 12 months follow-up.

\section{Discussion}

A search performed on PubMed database from January 1, 1998 to March 31, 2018 resulted in a total of 12 publications about VC, including case series and case reports [1-12] (Table 1). VC is a rare type of vulvar cancer with a characteristic of slow-growing, giant size, and less metastasis [1]. In our case, after laser treatment, this tumor grows more rapid than usual. This disease usually occurs in postmenopausal women, and some cases of young patients were also reported [12]. Most patients suffered from a long time of precursory symptoms, including bleeding, pruritus and pain (Table 2). In this review, the longest time of precursory symptom to diagnosis was 96 months $[2,10]$. An exophytic growth tumor with giant size was often presented, and the tumor often diffusely spread on the vulvar with both minor or major labia and mons or clitoris. Diagnosis of VC depends on pathology through biopsy. Since VC sometimes co-exist with SCC, biopsy might lead to misdiagnosis due to the superficial sampling [10]. A satisfying biopsy requires sufficient depth. In our case, the previous diagnosis is SCC and this indicated that a satisfying biopsy is very important for preoperative diagnosis.

According to the terminology of the International Society for the Study of Vulvovaginal Disease (ISSVD), 2 different types of squamous VIN were introduced in the 1986 ISSVD terminology and confirmed in 2004, "usual VIN" (HPV associated) and "differentiated VIN" (not HPV associated). Usual VIN and different VIN differ in clinical presentation, etiology, pathogenesis and histological/immunohistochemistry features [13]. The introduction of the Lower Anogenital Squamous Terminology (LAST) in 2016 changed the final version which was accepted by ISSVD as follows: 1)I low-grade SIL of the vulva or vulvar LSIL; 2) high-grade SIL of the vulvar or HSIL; 3) vulvar intraepithelial neoplasia, differentiated type [14]. The vulvar HSIL and the differentiated VIN are the precursors of the VSSC, leading to 2 separate pathways for developing VSCC. They have different risk factors, affect different populations and have different prognosis.

HPV infection only accounts for part of the VSCC. According to literatures, HPV status was evaluated in many VSCC cases and most of them were negative. HPV test were performed 

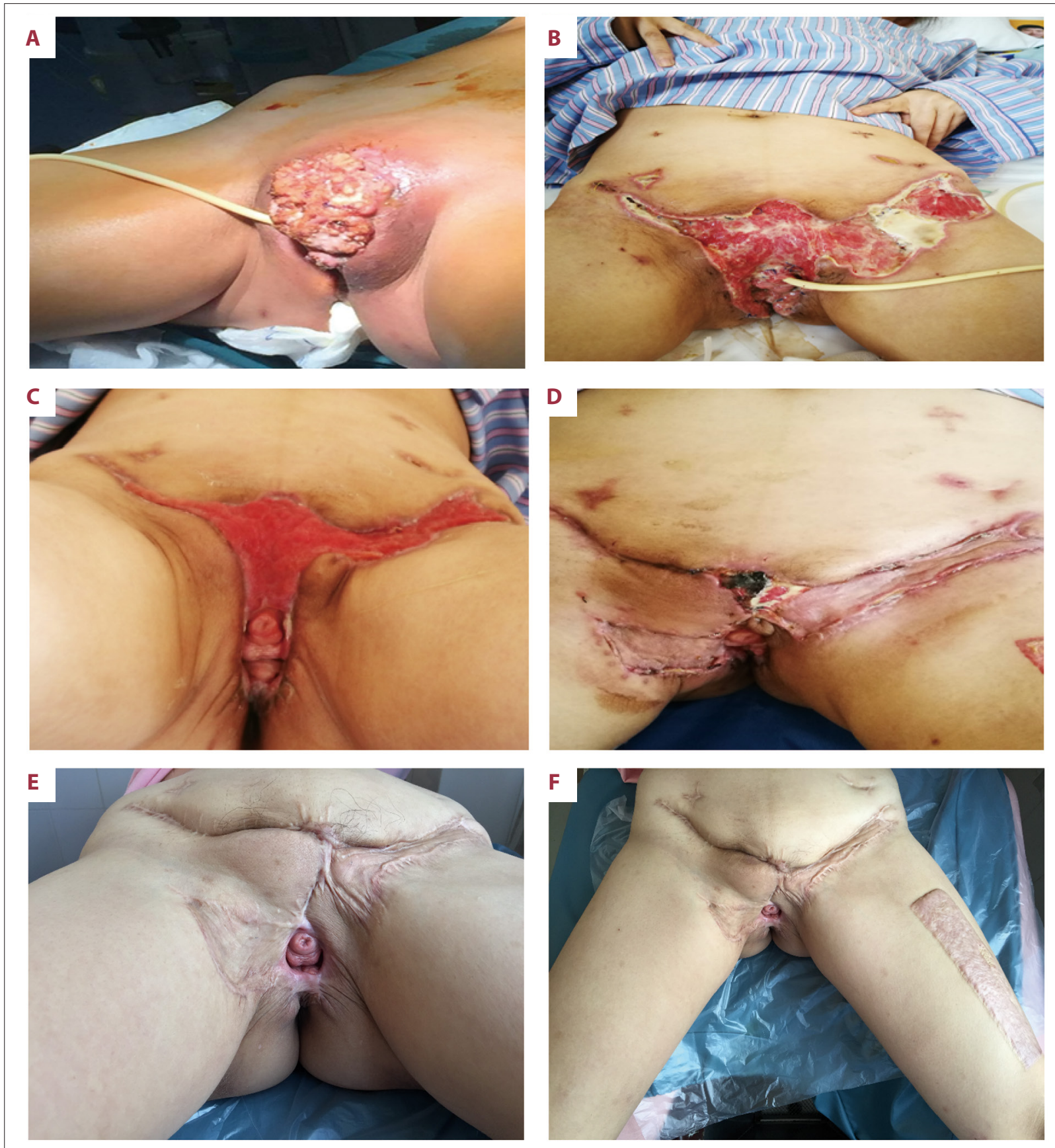

Figure 1. (A) Giant tumor on vulvar before primary surgery. (B) Large defection after tumor remove. (C) Defection before second surgery - vulvar reconstruction. (D) Appearance of vulvar after reconstruction. (E, F) Appearance of vulvar and pudendal thigh flap site at the last follow up.

in 20 patients, no patient with low-risk group infection and 1 patient suffered a multiple type of high-risk group infection $[1-4,9]$. The low detection rate might indicate that HPV infection and VC was not closely related.

Although surgery is the major treatment of VC, surgical procedures were different in different center due to the limited experience (Table 1). Simple or radical vulvectomy was commonly applied in those reviewed articles. Partial vulvectomy, extensive excision of the damage, and total deep vulvectomy were also performed. Although variety types of surgical procedures were performed, all authors recommend a tumor-free margin. Recent years, due to its favorable prognosis, surgical excision of primary tumor tends to be more conservative. For small tumor, 
Table 1. Clinical information summary of 50 cases.

\begin{tabular}{|c|c|c|c|c|c|c|c|c|c|}
\hline \multirow{2}{*}{ Author } & \multirow{2}{*}{$\begin{array}{l}\text { Published } \\
\text { year }\end{array}$} & \multirow{2}{*}{ Case(s) } & \multirow{2}{*}{$\begin{array}{l}\text { Invasion } \\
(\mathrm{mm})\end{array}$} & \multicolumn{2}{|c|}{ HPV infection } & \multirow{2}{*}{$\begin{array}{c}\text { Primary surgical } \\
\text { treatment }\end{array}$} & \multirow{2}{*}{$\begin{array}{l}\text { Lymph node } \\
\text { metastasis }\end{array}$} & \multirow{2}{*}{$\begin{array}{l}\text { Follow } \\
\text { up time } \\
\text { (months) }\end{array}$} & \multirow{2}{*}{ Status } \\
\hline & & & & Low-risk & High-risk & & & & \\
\hline $\begin{array}{l}\text { Tjalma WA } \\
\text { [3] }\end{array}$ & 2017 & 1 & $\begin{array}{l}\text { Deep into } \\
\text { the dermis }\end{array}$ & $(-)$ & $(-)$ & $\begin{array}{l}\text { Remove the } \\
\text { tumor with a } \\
\text { margin of } 1 \mathrm{~cm}\end{array}$ & $\begin{array}{l}\text { Sentinel node(-), } \\
\text { not done }\end{array}$ & 29 & $\begin{array}{l}\text { No signs of } \\
\text { recurrence }\end{array}$ \\
\hline $\begin{array}{l}\text { Campaner AB } \\
{[5]}\end{array}$ & 2017 & 1 & 10 & & NA & $\begin{array}{l}\text { Radical } \\
\text { vulvectomy with a } \\
\text { V-Y advancement } \\
\text { flap technique }\end{array}$ & $\begin{array}{l}\text { Only the palpable } \\
\text { lymph node in } \\
\text { the left inguinal } \\
\text { region was } \\
\text { excised, no sign } \\
\text { of metastasis }\end{array}$ & 4 & $\begin{array}{l}\text { No signs of } \\
\text { recurrence }\end{array}$ \\
\hline Liu G [1] & 2016 & 6 & & \multicolumn{2}{|c|}{$\begin{array}{l}\text { Performed in } 2 / 6 \text {, } \\
\text { both were }(-)\end{array}$} & $\begin{array}{l}\text { Surgical treatment } \\
\text { with tumor-free } \\
\text { margins }\end{array}$ & $\begin{array}{l}2 / 6, \text { no } L N \\
\text { involved }\end{array}$ & Mean 17 & $\begin{array}{l}\text { No signs of } \\
\text { recurrence }\end{array}$ \\
\hline $\begin{array}{l}\text { Bouquet de } \\
\text { Joliniere J } \\
\text { [6] }\end{array}$ & 2016 & 1 & 1.9 & \multicolumn{2}{|c|}{ NA } & $\begin{array}{l}\text { A partial } \\
\text { vulvectomy in our } \\
\text { department with } \\
\text { a vulvoplasty and } \\
\text { a replantation of } \\
\text { the clitoris }\end{array}$ & Not done & $>6$ & $\begin{array}{l}\text { No signs of } \\
\text { recurrence }\end{array}$ \\
\hline $\begin{array}{l}\text { Lorente Al } \\
\text { [7] }\end{array}$ & 2013 & 1 & NA & \multicolumn{2}{|r|}{ NA } & $\begin{array}{l}\text { A complete } \\
\text { vulvectomy and } \\
\text { clitoridectomy }\end{array}$ & $\begin{array}{l}\text { Sentinel node(-), } \\
\text { not done }\end{array}$ & NA & $\begin{array}{l}\text { No signs of } \\
\text { recurrence }\end{array}$ \\
\hline Boutas I [8] & 2013 & 1 & NA & \multicolumn{2}{|r|}{ NA } & $\begin{array}{l}\text { Extensive excision } \\
\text { of the damage }\end{array}$ & Not done & $>6$ & $\begin{array}{l}\text { No signs of } \\
\text { recurrence }\end{array}$ \\
\hline $\begin{array}{l}\text { lavazzo C } \\
{[9]}\end{array}$ & 2012 & 1 & 7 & Negative & $\begin{array}{c}\text { Type } \\
31-33\end{array}$ & $\begin{array}{l}\text { Radical wide } \\
\text { excision of the } \\
\text { tumor with free } \\
\text { surgical margins }\end{array}$ & Not done & 36 & $\begin{array}{l}\text { No signs of } \\
\text { recurrence }\end{array}$ \\
\hline $\begin{array}{l}\text { Haidopoulos D } \\
{[10]}\end{array}$ & 2005 & 17 & 1 & & NA & $\begin{array}{l}5 / 17 \text { radical } \\
\text { vulvectomy } \\
\text { +LND ( } 3 / 5 \text { biopsy } \\
\text { CSC,2/5 palpable); } \\
12 / 17 \text { simple } \\
\text { vulvectomy, } 2 \text { with } \\
\text { CSC+LND }\end{array}$ & $\begin{array}{l}7 / 17, \text { no LN } \\
\text { involved }\end{array}$ & $\begin{array}{l}51 \text { months } \\
\text { (range: } \\
13-119 \text { ) }\end{array}$ & $\begin{array}{l}\text { None died } \\
\text { of the } \\
\text { disease. } \\
3 / 17 \text { local } \\
\text { relapse, } \\
\text { and } \\
\text { managed } \\
\text { by wide } \\
\text { local } \\
\text { excision of } \\
\text { the tumour }\end{array}$ \\
\hline $\begin{array}{l}\text { Iwamoto I } \\
{[11]}\end{array}$ & 2004 & 1 & $\begin{array}{l}\text { Vascular } \\
\text { invasion } \\
\text { by the } \\
\text { tumor was } \\
\text { absent }\end{array}$ & & $(-)$ & $\begin{array}{l}\text { Total deep } \\
\text { vulvectomy with } \\
\text { en-block inguinal } \\
\text { femoral LND }\end{array}$ & no LN involved & 1 & $\begin{array}{l}\text { No signs of } \\
\text { recurrence }\end{array}$ \\
\hline $\begin{array}{l}\text { Nascimento } \\
\text { AF [4] }\end{array}$ & 2004 & 9 & NA & & $19(-)$ & NA & NA & NA & NA \\
\hline
\end{tabular}


Table 1 continued. Clinical information summary of 50 cases.

\begin{tabular}{|c|c|c|c|c|c|c|c|c|}
\hline \multirow{2}{*}{ Author } & \multirow{2}{*}{$\begin{array}{l}\text { Published } \\
\text { year }\end{array}$} & \multirow{2}{*}{ Case(s) } & \multirow{2}{*}{$\begin{array}{l}\text { Invasion } \\
\text { (mm) }\end{array}$} & \multirow{2}{*}{$\begin{array}{c}\text { HPV infection } \\
\text { Low-risk High-risk }\end{array}$} & \multirow{2}{*}{$\begin{array}{c}\text { Primary surgical } \\
\text { treatment }\end{array}$} & \multirow{2}{*}{$\begin{array}{l}\text { Lymph node } \\
\text { metastasis }\end{array}$} & \multirow{2}{*}{$\begin{array}{l}\text { Follow } \\
\text { up time } \\
\text { (months) }\end{array}$} & \multirow{2}{*}{ Status } \\
\hline & & & & & & & & \\
\hline $\begin{array}{l}\text { Gualco } M^{*} \\
{[2]}\end{array}$ & 2003 & 10 & NA & $\begin{array}{l}\text { Negative in } \\
\text { all cases }\end{array}$ & $\begin{array}{l}\text { Simple } \\
\text { vulvectomy- } \\
\text { radical } \\
\text { vulvectomy } \\
\text { (two radical } \\
\text { vulvectomy with } \\
\text { bilateral groin } \\
\text { LND) }\end{array}$ & $\begin{array}{l}\text { 2/10 in primary } \\
\text { surgery, another } \\
\text { underwent } L N \\
\text { after recurrence, } \\
\text { no LN involved }\end{array}$ & NA & $\begin{array}{l}\text { None died } \\
\text { of the } \\
\text { disease, } \\
\text { no signs of } \\
\text { recurrence }\end{array}$ \\
\hline $\begin{array}{l}\text { Massad LS } \\
{[12]}\end{array}$ & 1999 & 1 & NA & NA & $\begin{array}{l}\text { Anterior } \\
\text { exenteration } \\
\text { was performed, } \\
\text { with ileal conduit } \\
\text { construction, } \\
\text { omental } \\
\text { transposition, and } \\
\text { neovaginal } \\
\text { construction with } \\
\text { pudendal flaps }\end{array}$ & $\begin{array}{l}16 \text { removed } \\
\text { nodes showed } \\
\text { only reactive } \\
\text { changes }\end{array}$ & 16 & $\begin{array}{l}\text { No signs of } \\
\text { recurrence }\end{array}$ \\
\hline
\end{tabular}

NA - not available; CSC - co-exist with SCC; LND - lymph node dissection; LN - lymph node; * article written by pathologists.

Table 2. Clinical pathological characters of verrucous carcinoma of vulva.

\begin{tabular}{|c|c|}
\hline $\begin{array}{l}\text { Clinical pathological characters of VC of } \\
\text { vulva }\end{array}$ & \\
\hline Age (range), years & 32 to 93 \\
\hline Mean (range disease course, month) & 5 to 96 \\
\hline \multicolumn{2}{|l|}{ Symptoms (31 cases available) } \\
\hline Bleeding, pruritus, pain & $67.74 \%(21 / 31)$ \\
\hline \multicolumn{2}{|l|}{ Location (41 cases available) } \\
\hline Clitoris & $4.88 \% \quad(2 / 41)$ \\
\hline One side of minor or major labia or mons & $41.46 \%(17 / 41)$ \\
\hline Diffusely spread on the vulvar & $51.22 \%(21 / 41)$ \\
\hline Urethra or bladder involvement & $2.44 \% \quad(1 / 41)$ \\
\hline Tumor size $(\mathrm{cm})$ & 1 to 15.5 \\
\hline
\end{tabular}

wide local vulvectomy was performed, and for large size tumor, radical vulvectomy was often performed. As VC often with giant size, and resection of tumor often leave large skin defection. Skin or skin flap based vulvar reconstruction is an option for defect repair which might help wound healing and improve patient's quality of life. Lymph node dissection in VC is still controversial. In our study, preoperative imaging evaluation and physical examination suggested suspicious lymph node metastasis even with PET/CT scan. Therefore, we performed

\begin{tabular}{|c|c|}
\hline \multicolumn{2}{|c|}{$\begin{array}{c}\text { Clinical pathological characters of VC of } \\
\text { vulva }\end{array}$} \\
\hline \multicolumn{2}{|c|}{ Stage (FIGO 2015) (19 case available) } \\
\hline IA & $21.05 \% \quad(4 / 19)$ \\
\hline IB & $47.38 \% \quad(9 / 19)$ \\
\hline II & $26.32 \% \quad(5 / 19)$ \\
\hline III & 0 \\
\hline IVA & $5.26 \% \quad(1 / 19)$ \\
\hline IVB & 0 \\
\hline Adjuvant radiotherapy & $2.44 \% \quad(1 / 41)$ \\
\hline Coexistent SC (CSC) & $16 \% \quad(8 / 50)$ \\
\hline
\end{tabular}

a bilateral inguinal lymph node dissection, and bilateral pelvic lymph node dissection. However, consistent with the previous literatures, all lymph nodes were free of disease on histology. We reviewed 50 VC patients, among them lymph nodes status of 17 patients was assessed during surgery or by pathology.

All excised lymph nodes were free of disease. Previous study also illustrated the same phenomenon [1]. Liu et al. [1] reviewed 24 cases underwent unilateral or bilateral groin dissection or 
sampling and also found no lymph node involvement was detected. Although vascular invasion depth ranged from $1 \mathrm{~mm}$ to $10 \mathrm{~mm}$ in 5 patients, lymph node metastasis rarely occurs on VC. We speculated that simple or radical vulvectomy is sufficient for VC, systemic lymph node dissection might not be recommended as routine procedure for surgical therapy even in patients with large tumors. VC sometimes might coexist with SCC, and diagnosis might be affected by biopsy, if coexist with SCC is confirmed, further lymphadenectomy is needed after tumor dissection [10].

Only 1 patient underwent radiotherapy after surgery [8], and the other patients were follow-up regularly. Three patients suffered local relapse and received wide local excision [10], and there were no signs of recurrence of the other patients. No patient died of this disease. Therefore, we speculated that sufficient surgery is enough for VC and adjuvant therapy might not need.

\section{References:}

1. Liu G, Li Q, Shang X, Qi Z et al: Verrucous carcinoma of the vulva: A 20 year retrospective study and literature review. J Low Genit Tract Dis, 2016; 20(1): 114-18

2. Gualco M, Bonin S, Foglia G et al: Morphologic and biologic studies on ten cases of verrucous carcinoma of the vulva supporting the theory of a discrete clinico-pathologic entity. Int J Gynecol Cancer, 2003; 13(3): 317-24

3. Tjalma WA, Siozopoulou V, Huizing MT: A clitoral verrucous carcinoma in an area of lichen planus has aggressive features. World I Surg Oncol, 2017; 15(1): 7

4. Nascimento AF, Granter SR, Cviko A et al: Vulvar acanthosis with altered differentiation: A precursor to verrucous carcinoma? Am J Surg Pathol, 2004; 28(5): 638-43

5. Campaner AB, Cardoso FA, Fernandes GL, Veasey JV: Verrucous carcinoma of the vulva: Diagnosis and treatment. An Bras Dermatol, 2017; 92(2): 243-45

6. Bouquet de Joliniere J, Khomsi F, Gothuey JM et al: Verrucous carcinoma of the vulva: A case report and review of the literature. Front Surg, 2016; 3: 8

7. Lorente Al, Morillo M, de Zulueta T et al: Verrucous squamous cell carcinoma of vulva simulating multiple epidermal inclusion cysts. Indian J Dermatol, 2013; 58(4): 318-19

\section{Conclusions}

VC is a rare type of vulvar cancer with slow growing and giant size, but usually non-metastasis. Etiology of VC is still unknown. Surgery is the major treatment of VC, and enough margin is very import because inadequate might lead to local recurrence. Systemic lymph node dissection might not be recommended as routine procedure for surgical therapy. Outcome of VC promising based on correct diagnosis and appropriate treatment.

\section{Conflict of interest}

None.

8. Boutas I, Sofoudis C, Kalampokas E et al: Verrucous carcinoma of the vulva: A case report. Case Rep Obstet Gynecol, 2013; 2013: 932712

9. Iavazzo C, Fotiou S, Salakos N et al: HPV-related verrucous carcinoma of the vulva. A case report and literature review. Eur J Gynaecol Oncol, 2011; 32(6): 680-81

10. Haidopoulos D, Diakomanolis E, Rodolakis A et al: Coexistence of verrucous and squamous carcinoma of the vulva. Aust NZ J Obstet Gynaecol, 2005. 45(1): 60-63

11. Iwamoto I, Kijima $Y$, Fujino $T$ et al: Verrucous carcinoma of the vulva in Turner syndrome. Gynecol Oncol, 2004; 92(1): 380-83

12. Massad LS, Ahuja J, Bitterman P: Verrucous carcinoma of the vulva in a patient infected with the human immunodeficiency virus. Gynecol Oncol, 1999; 73(2): 315-18

13. Reyes MC, Cooper K: An update on vulvar intraepithelial neoplasia: Terminology and a practical approach to diagnosis. J Clin Pathol, 2014, 67(4): 290-94

14. Bornstein J, Bogliatto F, Haefner HK et al: The 2015 International Society for the Study of Vulvovaginal Disease (ISSVD) terminology of vulvar squamous intraepithelial lesions. Obstet Gynecol, 2016; 127(2): 264-68 